\title{
Implementation Of Online High School Online Acceptance Of New Students Policy At The Education Office Of North Sumatra Province
}

\author{
Afriani Rolenta Naibaho
}

Department of Public Administration Science, University Of North Sumatra, Indonesia.

\begin{tabular}{|c|c|}
\hline ARTICLE INFO & ABSTRACT \\
\hline Article history: & \multirow{9}{*}{$\begin{array}{l}\text { Implementation of the policy of New Student Acceptance (PPDB) } \\
\text { Online is a process of implementing well-formulated education } \\
\text { policy. Online PPDB Policy is used as a basis for implementing new } \\
\text { student acceptance system by online. to assess the success of the } \\
\text { implementation of PPDB Online policy can be seen from } 2 \text { major } \\
\text { variables namely policy content and policy implementation } \\
\text { environment. This objective is to find out how the implementation of } \\
\text { the policy of acceptance of new learners (PPDB) Online and see the } \\
\text { problems that arise when implementing the policies implemented by } \\
\text { the Education Office of North Sumatra province. The research } \\
\text { method used in this study is a qualitative approach in which the } \\
\text { study was a descriptive study is to determine or describe the reality } \\
\text { of events. Data collection techniques are Interviews, Observations, } \\
\text { and documents related to the research. Data analysis techniques in } \\
\text { this study were conducted qualitatively. This study uses nine policy } \\
\text { implementation variables from Merilee S Grindle covering the } \\
\text { interests of the target group, Type of benefits received, Degree of } \\
\text { change, Location of decision making, Program implementers, } \\
\text { Resources, power, interests, and strategies, Institutional } \\
\text { characteristics, Compliance level. From the research, it can be } \\
\text { concluded that the implementation of the policy of new student } \\
\text { enrollment (PPDB) at the middle school level has been running well } \\
\text { in terms of the content of the policy, the benefits received, the } \\
\text { expected changes, the location of the decision and the } \\
\text { Characteristics of Institutions and Regimes, The Power, Interest, } \\
\text { And Strategy Of The Actors Involved. However, in terms of policy } \\
\text { implementers, resources and compliance levels have not gone well. } \\
\text { It is inhibiting the success of the implementation of the policy of new } \\
\text { students (PPDB) Online. }\end{array}$} \\
\hline $\begin{array}{r}\text { Received Nov 04, } 2021 \\
\text { Revised Des 07, } 2021 \\
\text { Accepted Jan 30, } 2022\end{array}$ & \\
\hline \multirow{9}{*}{$\begin{array}{r}\text { Keywords: } \\
\text { Policy Implementation } \\
\text { New Student Acceptance } \\
\text { (PPDB) } \\
\text { Online }\end{array}$} & \\
\hline & \\
\hline & \\
\hline & \\
\hline & \\
\hline & \\
\hline & \\
\hline & This is an open access article under the CC BY-NC license. \\
\hline & (c) (i) (\$) \\
\hline \multicolumn{2}{|l|}{ Corresponding Author: } \\
\hline \multicolumn{2}{|c|}{$\begin{array}{l}\text { Afriani Rolenta Naibaho, } \\
\text { Department of Business Administration Science, } \\
\text { University Of North Sumatra, Indonesia, } \\
\text { Jl. Dr. Mansur No. } 9 \text { Padang Bulan, Kec. Medan Baru, Kota Medan } 20222 . \\
\text { Email: rolentanaibaho@gmail.com }\end{array}$} \\
\hline
\end{tabular}

\section{INTRODUCTION}

The use of information technology in Online Student Admission (PPDB) is a real step to encourage the creation of good governance in the education sector (Ardhi, 2015:83). PPDB was chosen, because it became the initial input of the education management process carried out by the school. 
If the input is managed properly, it is hoped that the continuation process can run well. Good governance is oriented to how to achieve goals effectively and efficiently, so that if the implementation of the PPDB Online program runs effectively and efficiently, good governance can be created in the education sector.

In response to the action plan from the Corruption Eradication Commission, the North Sumatra Provincial Education Office began implementing Online New Student Admissions (PPDB) for SMA and Vocational High Schools for the 2017/2018 academic year in accordance with Pergub Regulation No. 53 of 2017, regarding the procedures for implementing PPDB Online.

This Online Student Admission Program (PPDB) helps parents and prospective students so they don't have to bother with registration at a higher level of education. Registration is now more practical and efficient. However, in its implementation there are still some problems in the field, such as the discovery of "stealth students" students who enter illegally without taking part in the online selection by the Indonesian Ombudsman Representative for North Sumatra at two public high schools in Medan, namely SMA Negeri 2 Medan on Jalan Karang Sari, Medan District. Polonia and SMA Negeri 13 Medan on Brigadier General Zein Hamid Street, Medan Johor District, Medan City. At SMA 2 Medan, the Ombudsman found that there were as many as 180 new students who entered through unofficial channels.

Another problem that parents and prospective students also complain about is the website system which has problems that are very difficult to access even though the public and online PPDB participants want to immediately know the rankings on the day of the online PPDB implementation. (quoted from Medan.tribunnews.com/2017/06/22/pengumuman-ppdb-websitedisdik-overload) This condition is inversely proportional to one of the benefits to be achieved in implementing PPDB Online, namely to reduce the risk of collusion, corruption, nepotism (KKN) because the PPDB system is claimed to be integrated, accurate and transparent.

\section{RESEARCH METHOD}

The method used in this research is descriptive research method with a qualitative approach. According to Zuriah (2006:47) research using descriptive research methods is research that is directed to provide symptoms, facts, or events systematically and accurately / regarding the characteristics of a particular population or area.

In this study, a researcher will develop concepts and collect facts but will not test hypotheses (singarimbun 1989:4-5).

The form of qualitative descriptive research is to collect information or field data related to the extent to which the interests of the target group or target group are contained in the content of the policy, the types of benefits received by the target group, the degree of change, the location of decision making, program implementers, resources used, power, the characteristics of the institutions and regimes in power, the level of compliance and the response from the implementers"

In this study, the author uses a type of data triangulation. The data source triangulation technique is carried out by comparing the data obtained through interviews between research subjects with one another. The data can be said to be valid if there is consistency or conformity between the information provided by one informant with other informants regarding the implementation of the online high school level new student admissions policy (PPDB) at the education office of the North Sumatra province.

\section{RESULTS AND DISCUSSIONS}

\subsection{The interests of the target group or target groups are contained in the content of the policy}

One of the main keys to quality policy management is the high intensity of public participation. The main purpose of participation is to bring together all the same and different interests in a process of formulating and determining policies (decisions) proportionally for all parties involved 
and affected by the policies that will be set in it. an effective way to accommodate and accommodate various diverse interests. (Lijan P Sinambela, 2006: 37).

A policy is made with the aim of obtaining a better situation than the previous situation, as is the case with public policy in the field of education, namely the Online New Student Admission (PPDB) policy at the high school level. The policy of the student admission system greatly affects the continuity of learning activities in schools. Without students, the school cannot function properly. In addition, a student admission system policy is also needed as an effort to maintain its existence as an educational institution, namely schools.

Interests affected by the policy group concerns the extent to which the interests of the target group are contained in the content of the policy. These interests relate to various interests that have an influence on a policy implementation. This indicator has an argument that the implementation of a policy must involve many interests, and the extent to which these interests influence its implementation. The parties whose interests are influenced by this Online New Student Admission (PPDB) policy are:

Table 1. Parties Related to the Interests of PPDB Online

\begin{tabular}{|c|c|c|c|}
\hline No & Interested Parties & & Interest \\
\hline 1 & $\begin{array}{l}\text { Commission } \\
\text { (KPK) }\end{array}$ & Corruption & 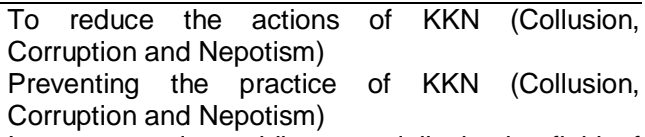 \\
\hline 2 & North Sumatra Provincial Education Office & & $\begin{array}{l}\text { Increase service public, especially in the field of } \\
\text { education } \\
\text { Improving the quality of education }\end{array}$ \\
\hline 3 & PPDB Online user community & & $\begin{array}{l}\text { Effective, transparent and accountable public } \\
\text { services } \\
\text { Equitable education }\end{array}$ \\
\hline
\end{tabular}

Source: North Sumatra Provincial Education Office

The Online New Student Admissions Policy (PPDB) at the High School Level was made based on public complaints to the Ombudsman about frauds that often occur when accepting new students such as bribes, deposited students and superior school problems that can only be entered by certain people only. Therefore, the North Sumatra Provincial Government, especially the North Sumatra Provincial Education Office, carries out the policies included in the KPK action plan, namely implementing the acceptance of new students with the Online system.

In the Indonesian government regulation Number 17 of 2010 concerning the management and implementation of education, in particular Article 72 (paragraphs 1 and 2) and Article 82 (paragraphs 1 and 2) concerning the acceptance of students in primary or secondary education units must be objective, transparent, accountable, and non-discriminatory.

\subsection{Types of Benefits Received By The Target Group}

In policy content, policy benefits seek to show and explain that in a policy there must be several types of benefits that contain and produce positive impacts by implementing the policies to be implemented. Benefit refers to anything that society, or community group leaders, view as desirable. A policy that is intended to provide collective benefits will usually be more readily implemented when compared to a policy that has particular benefits (for some people).

Public policy is essentially a government intervention that aims to change existing conditions or influence the direction and speed of changes that are taking place in society in order to realize the desired conditions. (Said. Z. Abidin. 2002: 4).

The intervention is carried out through one or a series of policy strategies using various policy tools to bring benefits to the community as well as to the implementers of the policy. One form of intervention is the implementation of the Online New Student Admission Policy (PPDB) at the High School Level at the North Sumatra Provincial Education Office.

\subsection{Desired Degree of Change}


The implementation of a policy is basically a multi-organizational change or transformation, where the changes implemented through this policy implementation strategy link various levels of society. (Mulyadi Deddy, 2016: 26).

A policy is designed in such a way as to create a change in the environment and behavior of an individual or group of people. These changes may involve changes in social, political and economic relations. The success of policy implementation is largely determined by the right policies that are able to accommodate various views and different interests in society. With the implementation of the Online New Student Admission (PPDB) policy, the government hopes that there will be changes that are accepted by the community and of course changes that can have a positive impact on the community as well as for the implementers.

Online New Student Admission (PPDB) is a system that is 100\% website-based and this is the first time it has been implemented in the province of North Sumatra as well as in Indonesia because so far in other areas PPDB Online has only been implemented at the district level, this is what makes PPDB Online. entered as one of the North Sumatra government's breakthrough programs. One of the changes to be achieved in the implementation of PPDB Online is to avoid cheating loopholes that usually occur at the time of admission of new students so that through this system it is hoped that there will be no more fraudulent actions that can harm several parties as stated by the Head of the Program Subdivision, Duties of Assistant and Public Information Disdikprovsu. The following is an excerpt from the researcher's interview with him:

"This PPDB Online is an action plan from the KPK as a result of the many findings from the ombudsman regarding fraud that occurred during the new student admissions process so that by implementing this online PPDB, it is hoped that there will be no more cases of entrusted students, bribes and other fraud. Besides that, with this online PPDB, there are no more excellent schools because with a system like this all schools are excellent, so all schools improve their respective schools." (See interview transcript about the location of PPDB Online decision makers, p. 4)

PPDB Online was implemented because in the implementation of student admissions in the province of North Sumatra so far it has experienced various problems, namely:

a. Lack of transparency and accountability in the implementation of PPDB

b. Inefficient implementation of PPDB

c. Low quality of education services

d. Invalid education data availability

The following is the flow of thought for the implementation of PPDB Online in the Province of Sumatra North :

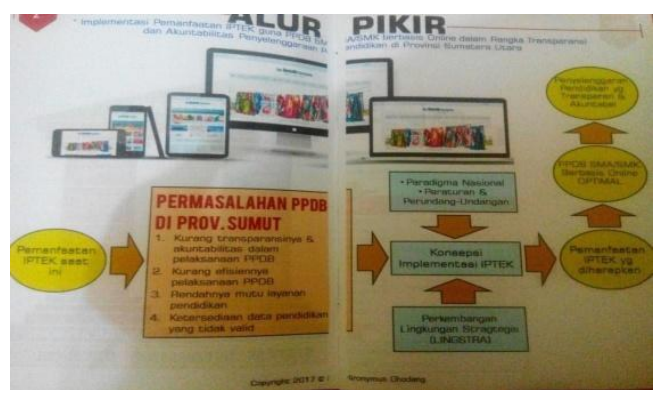

Figure 1. Flowchart of PPDB Online Implementation

Source: Documentation results on the PPDB Online implementation flow

That is why the North Sumatra provincial government, especially the Education Office, has implemented an action plan program from the Corruption Eradication Commission (KPK) to carry out online acceptance of new students by utilizing advances in information technology because this system is considered to be able to correct deficiencies that usually occur at the time of admission. new students so that it is hoped that they can change the way the education office works and 
change the behavior of people who have been accustomed to bribery activities so that they can enter certain schools now with this system it is no longer possible.

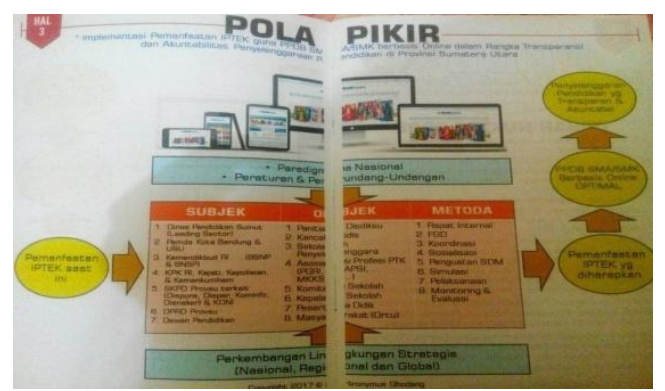

Figure 2. PPDB Online Implementation Mindset

Source: Documentation results about the mindset of implementing PPDB Online

In addition to bringing changes to the way the Education Office works, the implementation of PPDB Online also brings changes to the PPDB Online user community where this Online system is completely different from the previous manual registration. To register for public schools, they must use technology, namely the internet, the community no longer needs to come to the school that he wants to register but simply comes to the school closest to his home, fill in the registration form to get an account to login to the PPDB website. At this stage, prospective students register for the school they want. .

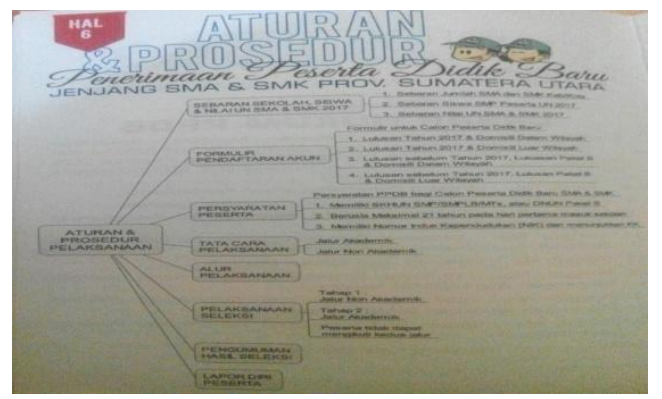

Figure 3. Flow of PPDB Online Implementation

Source: Documentation Results on PPDB Online registration flow

With the implementation of PPDB Online, the community feels very big changes in various fields such as in the field of Social Affairs, the opportunity for smart students to enter their favorite schools can be maintained even though they are classified as poor students because so far only people who have money have been able to enter superior schools. many now with the PPDB Online system these things can no longer happen because what works is the system if the student meets the criteria then he automatically enters so this system also enforces justice for the community, while in the economic field the community also benefits from this system because there are no more gaps for bribes and the PPDB Online registration process also does not charge a fee, everything is free, the public is given the convenience of registering for PPDB Online.

\subsection{Level of Compliance and Responsiveness of the implementing group}

Compliance and response from the target groups is also felt to be an important aspect in the process of implementing a policy. In the implementation of the Online New Student Admission Policy (PPDB) there are still some service users who do not comply with the regulations, this is evident from the discovery of illegal students who enter without the PPDB Online route by the Ombudsman. This finding is in SMAN 2 Medan with a total of 180 students and at SMAN 13 Medan with a total of 72 students. 
This is one of the indicators that causes the unsuccessful implementation of PPDB Online at the high school level, when many parties are trying to provide the best, open and accountable service and in accordance with the demands of the community. It turns out that there are still some people who are not ready for an open system.

Knowing that there were problems when implementing the Online Student Admission (PPDB), the Education Office immediately coordinated with private schools so that students who were classified as illegal students immediately moved to private schools without having to pay development money because they really couldn't go to the schools they register because their names are not registered in the basic education data so it's useless for them to force them to go to school there because there will be no use, explained Dapodik Admin, APK/APM. Here's an excerpt from the interview: "We responded by facilitating them to move to private schools that were closest to the previous school, so that the students would be enrolled in the dapodik" (See transcript of the interview on the response of the executor to the problem of illegal students, p. 12).

This condition has undermined the success of the implementation of the Online New Student Admission (PPDB) policy at the High School Level at the Education Office of North Sumatra Province.

\section{CONCLUSION}

The implementation of the online new student admissions policy (PPDB) at the high school level at the North Sumatra provincial education office generally has not gone well, seen from the 9 important variables of the process of implementing the online new student admissions policy (PPDB) as stated by Merile S. Grindle, namely: the interests of the target group or target groups are contained in the content of the policy. Judging from the contents of the Online Student Admission (PPDB) policy, it was made to be able to provide the best service for the community, especially in the field of education. mandated to carry out the process of accepting new students objectively, transparently and effectively. The contents of the policy are in accordance with the interests of the people who need good service.

Types of Benefits Received by the Target Group, with the implementation of Online New Student Admission (PPDB) the people who are the targets of this policy can feel the benefits starting from a more effective way of registration, and access to services that can be opened for 24 hours and are transparent so all parties interested parties can oversee this system, in addition to the benefits for users of the implementation of the new student admissions policy, it also provides benefits for the education office as the implementer of the policy, namely they can improve their performance.

Desired Degree of Change. With the implementation of the Online New Student Admission (PPDB) policy, the expected change is that there will be no more fraudulent acts that usually occur at the time of registration of new students such as the problem of depositing students and giving bribes and it is hoped that all parties involved will obey the rules because with this system the admission process new students are more transparent and accountable, but in reality in the field there are still people who do not obey the rules of PPDB Online where there are still some people who try to send their children to certain schools such as SMAN 2 and SMAN 13 Medan by giving bribes. the success of the Implementation of PPDB Online at the High School Level at the North Sumatra Provincial Office

Location of Decision Making. This Online New Student Admission Policy (PPDB) was made based on the action plan from the Corruption Eradication Commission (KPK) as a form of preventing Collusion, Corruption, Nepotism (KKN) actions during the process of accepting new students and this action plan from the KPK received full support from North Sumatra government by appointing the provincial education office to implement this policy and make PPDB Online into the North Sumatra government's flagship program.

Program Executor. The implementer of the Online New Student Admission (PPDB) policy is the North Sumatra provincial education office by forming an implementing committee consisting of the education office and the school. handle the implementation of PPDB in their area and in carrying out their duties are under the supervision of the KPK. 
Resource. In implementing the Online New Student Admission (PPDB) the education office which is authorized to implement this policy uses human resources by empowering 9 programmers from outside the service and one from within the education office to design the PPDB Online website system. This proves that the education office lacks professional experts. Apart from human resources, there are still many people who do not receive socialization or information regarding the implementation of PPDB Online. This is what hinders the Implementation of PPDB Online The Powers, Interests, and Strategies of the Actors Involved. In the implementation of PPDB Online, it has full support from the provincial government of North Sumatra and is also under the supervision of the KPK and the strategy used to make this policy a success is to use technological advances where with technology, there is less space for fraudulent practices because those who work is a system whose performance can be monitored 24 hours by the public. From the results of PPDB Online, the Ombudsman found illegal students because when re-collecting school data they found a number of student names that were not registered in the PPDB Online results.

Characteristics of Institutions and Regimes in Power. In the implementation of PPDB Online, the education office gets support from the government, where the government facilitates all Admins per district/city by providing 1 laptop unit to support the success of implementing PPDB Online. Level of Compliance and Responsiveness of the implementing group. The implementation of the PPDB Online Policy at the High School Level at the North Sumatra Provincial Education Office has not gone well, this is evident from the community's disobedience to this regulation as evidenced by the discovery of a number of illegal students entering SMAN 2 and SMAN 13 Medan without going through the PPDB Online route even though the rules are very clear that if you want to enter high school education you must go through the online registration process, this is evidence of the community's unpreparedness for an open system, apart from the community from within the education office, namely the principal who also plays with PPDB Online regulations, this is evident from the replaced the position of principal in the two SMANs.

\section{REFERENCES}

Akib, Header. 2009. Dasar-Dasar Teori Organisasi. Makassar : Universitas Negeri Makassar.

Agustino. 2008. Dasar-dasar Kebiajakan Publik. Bandung: Alfabeta.

Arifianto,S. 2013. Dinamika Perkembangan Pemamfaatan Ternologi Informasi dan Komunikasi Serta Implikasinya Di Masyarakat. Jakarta: Media Bangsa.

Arikunto, S. 2006. Prosedur Penelitian Suatu Pendekatan Praktik. Jakarta: PT.Rineka Cipta.

Emzir. 2010. Isu-Isu Kritis Kebijakan Pendidikan Era Otonomi Daerah. Jakarta: Graha Indonesia.

Huntington, Samuel P. 1986. Political Order in Changing Societies. Yale University Press. New Haven.

H, Solichin Abdul W. 2008. Pengantar Analisa Kebijakan Publik. Malang: UMM Press

Lijan Poltak Sinambela, dkk. (2008). Reformasi Pelayanan Publik: Teori, Kebijakan, dan Implementasi. Jakarta: PT Bumi Aksara.

M. Amirin, Tantang. 2000. Menyusun Perencanaan Penelitian. PT Rajagrafindo Persada. Jakarta. HIm 84.

Moleong, Lexy J. 2007. Metodologi Penelitian Kualitatif. Bandung: PT Remaja Rosdakarya Offset.

Mulyadi, Deddy. 2016. Studi Kebijakan Publik Dan Pelayanan Publik. Bandung: Alfabeta

Nugroho, Riant. 2008. Public Policy. PT Elex Media Komputindo: Jakarta Rochaety, Eti. dkk. (2009). Sistem Informasi Manajemen Pendidikan. Jakarta: Bumi Aksara.

Robbins P Stephen. 2015. Teori Organisasi: Struktur, Desain dan Aplikasi, Jakarta : Arcan Sadler, Philip. 1994. Mendesain Organisasi. Jakarta: Pustaka binaman pressindo.

Santoso, pandji, 2009. administrasi publik : teori dan aplikasi good governance. Bandung : PT. Refika Aditama singarimbun \& effendi, 1989, Metode Penelitian Survei, Jakarta: LP3ES.

Subarsono, 2005. Analisis Kebijakan Publik. Yogyakarta: Pustaka pelajar.

Sugiyono. 2016. Metode Penelitian Kualitatif Dan R\&B. Bandung: Alfabeta. Tahir, Arifin. 2014. Kebijakan Publik dan Transparansi Penyelenggaraan Pemerintah Daerah. Alfabeta. Gorontalo.

Tangkilisan, Hesel Nogi. 2003. Implementasi kebijakan publik : transformasi pikiran George Edward. Yogyakarta : Lukman Offset dan yayasan pembaruan administrasi publik indonesia. Hesel Nogi. 2003. Kebijakan Publik Yang Membumi. Yogyakarta: Lukman Offset.

Winarno, Budi. 2002. Teori dan Proses Kebijakan Publik. Yogyakarta: Medpress.

Wirawan. 2011. Evaluasi : Teori, model, standar, aplikasi, dan profesi. Rajawali press. Jakarta. Hal 156-159

Zuriah, N. 2006. Metodologi Penelitian Sosial dan Pendidikan : Teoei Aplikasi. Jakarta: Bumi Aksara. 
Andreas Wintoko. Implementasi Pelayanan Publik Program Penerimaan Peserta Didik Baru Melalui Sistem Online (Studi di SMAN 1 Banyuwangi dan SMAN 1 Singojuruh Kabupaten Banyuwangi). Jurnal ilmu administrasi publik Vol 4, No 4 (2016).

Ardhi, Mohammad imam. 2015. Evaluasi Manajemen Penerimaan Peserta Didik Baru Sistem Real Time Online Dinas Pendidikan Kota Yogyakarta. Jurnal penelitian ilmu pendidikan.vol 8 No.1 hal 80-94.

Sopiatno basofi. implementasi kebijakan penerimaan peserta didik baru (PPDB) online tingkat sekolah menengah atas di kota pekan baru tahun 2011-2013. Jom FISIP Volume 2 No. 1-february 2015.

Tri Murwaningsih. "Implementasi Penjaminan Mutu di Fakultas Keguruan dan IImuPendidikan Universitas Sebelas Maret”. Jurnal Inovasi Pendidikan. Vol. 10, No. 1.(Surakarta, Mei 2009), 91-101.

Mira A Nur. 2016. efektifitas penerimaan peserta didik baru (PPDB) Online di dinas pendidikan dan kebudayaan kota makassar. Skripsi. Program sarjana Administrasi Negara. Universitas Hasanuddin. Makassar.

Setiawan Dedi. 2016. Implementasi kebijakan penerimaan peserta didik baru sekolah menengah atas sistem real time online (RTO) di kabupaten Bnatul tahunpelajaran 2015/2016. Skripsi. Program sarjana Administrasi Pendidikan. Universitas Negeri Yogyakarta. Yogyakarta.

Wulansari Devi. 2016. Kebijakan Sistem Penerimaan Peserta Didik Baru Di Sekolah Menengah Kejuruan Negeri 1 Cangkringan Sleman Yogyakarta. Skripsi. Program sarjana Administrasi Pendidikan. Universitas Negeri Yogyakarta. Yogyakarta.

Peraturan pemerintah RI Nomor 17 Tahun 2010 tentang pengelolaan dan penyelenggaraan pendidikan.

Undang-undang Nomor 20 tahun 2003 tentang sistem pendidikan Naisonal Peraturan pemerintah RI Nomor 17 Tahun 2010 pasal 74 (ayat 1 dan 2) dan pasal 82 (ayat 1 dan 2) tentang penerimaan peserta didik pada satuan pendidikan dasar/menengah. 